\title{
DATING THE IRRIGATION SYSTEM OF THE SAMARKAND OASIS: A GEOARCHAEOLOGICAL STUDY
}

\author{
Luca C Malatesta ${ }^{1,2} \cdot$ Sébastien Castelltort $^{1,3} \cdot$ Simone Mantellini $^{4} \cdot$ Vincenzo Picotti $^{5}$ • \\ Irka Hajdas ${ }^{6}$ Guy Simpson ${ }^{7} \cdot$ Amriddin E Berdimuradov $^{8} \bullet$ Maurizio Tosi $^{4} \bullet$ Sean D Willett ${ }^{1}$
}

\begin{abstract}
The oasis of Samarkand in the Middle Zeravshan Valley (modern Uzbekistan) was a major political and economic center in ancient western Central Asia. The chronology of its irrigation system was, until now, only constrained by the quality and quantity of archaeological findings and several different hypotheses have been proposed for it. We use a new approach combining archaeological surveying, radiocarbon dating, sedimentary analysis, and the numerical modeling of a flood event to offer new evidence for, and quantitative dating of, the development of irrigation system on the southern flank of the Middle Zeravshan Valley. We analyzed 13 bones and charcoals from 3 archaeological sites and obtained new ${ }^{14} \mathrm{C}$ ages from Afrasiab (ancient Samarkand), a dwelling damaged by flooding in the 2nd century AD (site code: SAM-174) and the fortress of Kafir Kala. We established the origin of sedimentary deposits at the sites to infer the presence of the 2 most important canals of the southern flank: the Dargom and the Yanghiaryk. Finally, we show with a numerical model of overland flow that a natural flood was unlikely to have produced the damage observed at SAM-174. The combined results of the study indicate that the canals south of Samarkand existed, and were mainly developed, in the 2nd century AD and were not connected to the main feeding canal of Afrasiab at that time.
\end{abstract}

\section{INTRODUCTION}

The human development of Central Asia's main centers was long sustained by large regional-scale irrigation systems (Lewis 1966; Andrianov 1969, 1995; Francfort and Lecomte 2002). The oasis of Samarkand in the Middle Zeravshan Valley, Uzbekistan, is no exception. It is based on 2 major canals: the Dargom in the south and the Bulungur in the north. Despite the semi-arid conditions of western Central Asia (Oberhänsli et al. 2007), the water supplied by those canals made this region one of the few agricultural heartlands of Central Asia (Shirinov and Tosi 2003). In the present study, we focus on the southern flank of the Samarkand Oasis, where the irrigation system upstream from Afrasiab (i.e. ancient Samarkand) consisted of the large - and still preserved today —Dargom Canal, and of its smaller auxiliary, the Yanghiaryk Canal, which was rebuilt during Soviet times (Figure 1).

Recent research shows that the Dargom Canal was built by successively merging the small piedmont streams of the valley's southern streams, or sais (we use this Uzbek term hereafter for nonperennial tributary streams) and, finally, by diverting part of the Zeravshan waters into large hillside canals (Isamiddinov 2002; Marconi et al. 2009; Stride et al. 2009; Mantellini et al. 2011). Hypotheses as to the age of the Dargom Canal are mainly based on archaeological data from regional surveys or, less frequently, from stratigraphic excavations. There has been no direct quantitative dating of the Dargom. The hypotheses differ widely and propose various construction times: during the 1 st half of the 1 st millennium BC (Isamiddinov 2002), in the Achaemenid period (6th-4th centuries BC) connected to a strong central state (Shishkina 1987; Grenet 2002), at the turn of the Current Era (Gulyamov 1975; Mukhamedjanov 1975, 1996), as a result of a collaborative effort within a noncentralized society during the 1st half of the 1st millennium AD (Stride et al. 2009), or even as late as the early Mid-

\footnotetext{
${ }^{1}$ Institute of Geology, ETH Zurich, Switzerland.

${ }^{2}$ Now at the Division of Geological and Planetary Science, California Institute of Technology, USA. Corresponding author. Email: luca@caltech.edu.

${ }^{3}$ Now at the Section of Earth Sciences, University of Geneva, Switzerland.

${ }^{4}$ Department of Archaeology, University of Bologna, Italy.

${ }^{5}$ Department of Earth and Environmental Sciences, University of Bologna, Italy.

${ }^{6}$ Laboratory of Ion Beam Physics, ETH Zurich, Switzerland.

${ }^{7}$ Department of Geology and Paleontology, University of Geneva, Switzerland.

${ }^{8}$ Academy of Sciences of Uzbekistan, Institute of Archaeology of Samarkand, Uzbekistan.
} 

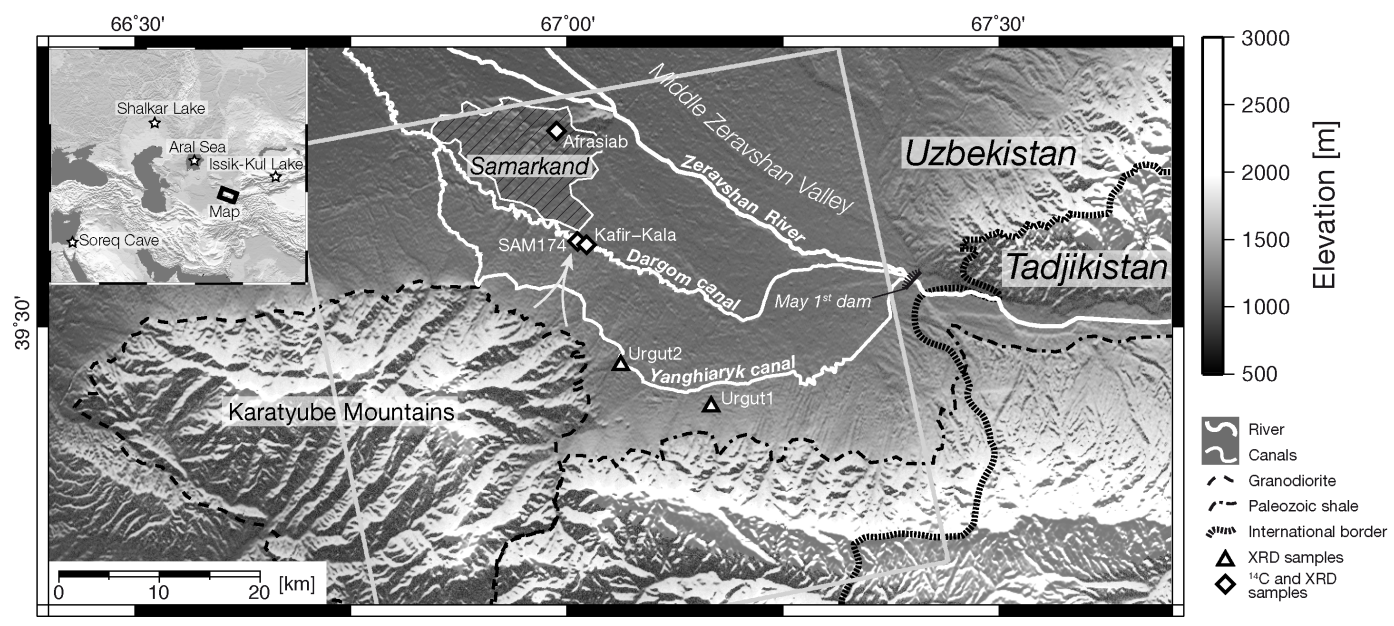

Figure 1 Map of the Middle Zeravshan Valley

dle Ages (Lebedeva 1994; Askarov 1995). Although the Yanghiaryk is crucial for the irrigation of the strip of land uphill from the Dargom (Bartold 1977), it was never the subject of any particular study.

The opportunity to better understand the chronological relationship between the development of the irrigation system and the settlement dynamics has been provided by new excavations at the site SAM-174 (Figure 1). This small settlement on an artificial mound, called tepa in Farsi, is located $1 \mathrm{~km}$ northwest of the Kafir Kala fortified complex, a larger site under investigation by the UzbekItalian Archaeological Expedition in Samarkand (Mantellini and Berdimuadov 2005). The preservation of the tepa SAM-174 has been adversely affected by the use of the site as a mudbrick factory. However, this activity also revealed a section at its western border where layers of gray sands were discovered and interpreted as evidence of an ancient flood event covering a layer of pottery artifacts.

Investigating sedimentological and surface processes in addition to the current observations at the tepa SAM-174, the neighboring fortress of Kafir Kala, and the city of Afrasiab, we discuss the pattern and nature of the overland flow at the time of the floods as well as the timing of the establishment of the Dargom. To constrain the chronology of the irrigation system, we first radiocarbon dated the floods using bones and charcoals from the flooding horizons. We subsequently employed X-ray diffraction (XRD) to discriminate between artificial and natural channels. XRD study of channel deposits yields the mineralogical composition of the sediments, which indicates their provenance. Finally, a numerical model of surface overflow (Simpson and Castelltort 2006) constrains the dynamics of the possible floods within the topographic surroundings of the archaeological sites. We also looked for the oldest record of the Dargom in the stratigraphy of Kafir Kala and tested if the contemporaneous irrigation of Afrasiab was derived from this canal as was previously proposed (Gentelle 2003).

\section{REGIONAL SETTINGS AND SAMPLING STRATEGY}

The Middle Zeravshan Valley begins where the Zeravshan River, flowing westwards, leaves the narrow and steep upper valley, in the Tadjik Tian Shan, to enter a 60- to 100-km-wide section of the valley in Uzbekistan (Figure 1). Further west, the Zeravshan River flows into the Bukhara Oasis and then into an irrigation network linked to the Amu Darya River. The broad gentle slopes of the Mid- 
dle Zeravshan Valley are extensively used for agriculture, which is sustained by an irrigation system tapping its water from the Zeravshan River. Two main irrigation canals, the Dargom and the Yanghiaryk, are derived from the Zeravshan at the height of the modern May 1st Dam at the Uzbek-Tajik border and traverse the southern valley slope. The Dargom Canal is still in use today and has evolved into a meandering channel after incising more than $20 \mathrm{~m}$ in its original bed (Mantellini 2003; Marconi et al. 2009). The Yanghiaryk Canal has been extensively reworked and is now channelized in a concrete bed. No clear traces of its original bed have been found, but its presence was inferred by historical sources (Bartold 1977) and the study of sediment deposits (this study).

The development of the irrigation system has consequences for the sedimentary deposits on the cultivated southern slopes of the Zeravshan Valley. The canals altered the provenance of the sediments deposited on irrigated land. As a result, the local red sands were covered by dark gray sands, derived from the Zeravshan River, wherever land was irrigated and cultivated (Fedchenko 1870).

The sedimentary facies outcropping in local trenches is always characterized by a strong color difference between local ochre-red sediments of thick hillslope fan deposits (Figure 3d), and dark gray sand originating in the Zeravshan River and borne by the canals. This is particularly striking at the modern confluence of small sais and irrigation canals (Figure 2a). It results in a zonation of the stratigraphy as either ochre-red, dark gray, or interfingered ochre-red dark gray sedimentary deposits (Figure 2b).
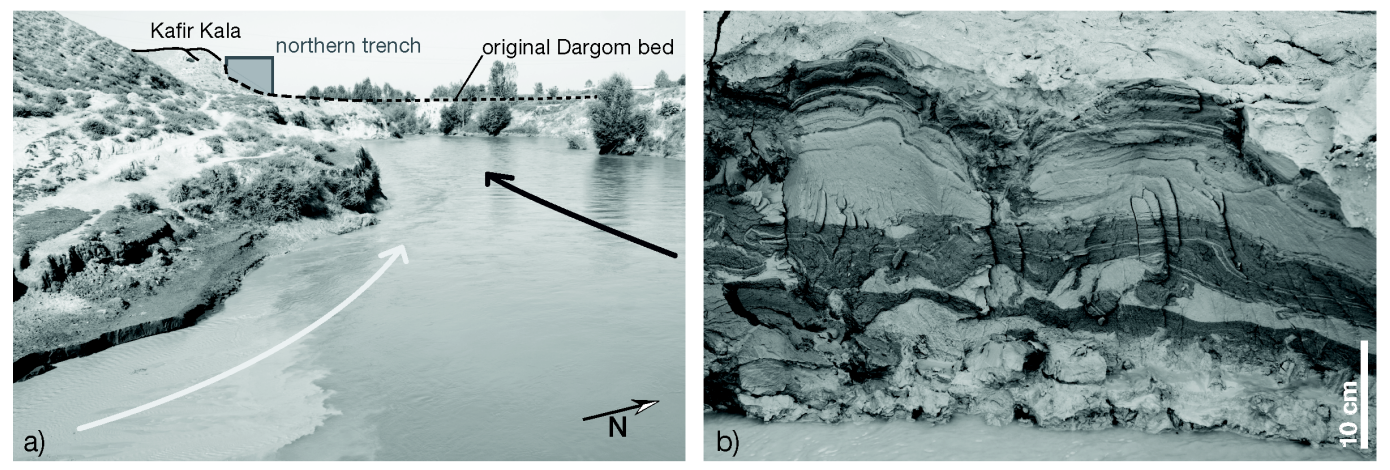

Figure 2 a) Difference in sediment color at the confluence of the Ilonsai, a side stream, and the Dargom Canal—light gray is ochre-red and darker gray is dark gray (see Figure 4a for detailed map). The picture was taken looking NNW; the large left bank in the background is the original bed of the Dargom Canal. On its left, the higher plateau indicates the position of the site of Kafir Kala. The rectangle designates the position of the northern trench dug in Kafir Kala (see Figure 4). The point of view of this picture is marked in Figure 4a. b) Interfingering of the 2 lithologies in the sediments of the modern Dargom: dark gray from the Zeravshan catchment; and ochre-red (light gray in the picture) from local side slopes.

Material for ${ }^{14} \mathrm{C}$ dating and XRD analysis was sampled in 3 archaeological sites: the small settlement of SAM-174; the fortress of Kafir Kala; and Afrasiab. Two additional samples for XRD analysis of sediment sources were obtained from stream beds (Figure 1). The tepa SAM-174 lay at the foot of a 2000 -m-asl topographic ridge, the Karatyube Mountains, whose hillslopes are a potential source area for the flooding water. The white arrow in Figure 1 designates the hypothesized source and flow direction of the flooding event.

\section{DESCRIPTION OF SAMPLING SITES}

SAM-174 $\left(39.576263^{\circ} \mathrm{N}, 67.011871^{\circ} \mathrm{E}\right)$ is the main investigation site of this study. The tepa lies close to the Dargom, $7 \mathrm{~m}$ above its original bank. Like many other archaeological sites spread over 
the territory of Samarkand, it was built with mudbricks and pakhsa, a traditional construction material made of a mixture of mud and straw, forming blocks of roughly $1 \mathrm{~m}^{3}$. According to the stratigraphic sounding carried out in the western side of the tepa, the site might have functioned as a watermill fed by small canals called aryks in Russian (we use hereafter the Russian term for small ditches derived from a main canal) derived from a larger canal linking the Yanghiaryk Canal to the Dargom Canal along a SE-NW axis (Figures 3c and 4a) (Berdimuradov et al. 2010). The use of the site as a mudbrick factory destroyed the SW upstream extension of those aryks. During the September 2009 season, a NW-SE profile cut in the tepa (Figure 3a) revealed small hollows ( 1 m deep) filled with cross-stratified coarse gray sand deposited by a single event of flooding. The deposit also contains a tilted block of pakhsa (possibly a wall) with a large number of archaeological artifacts on the lee side, while the stoss side remained free of any such historical items. We hypothesize that the wall collapsed due to the heavy flooding. The $3{ }^{14} \mathrm{C}$ samples are indicated by crosses on the photograph. The samples SAM174-2 and SAM174-3 were taken in the coarse gray sand layer covering the debris of the flood. Sample SAM174-1 was picked at the bottom of a hollow that might have been a small water basin, below the dark mass of the flood unit (Figure 3b). The stratigraphy of the fan deposits south of the Zeravshan contains several units of very coarse red sand with rounded pebbles. They are identified as local flood deposits (Figure 3d).

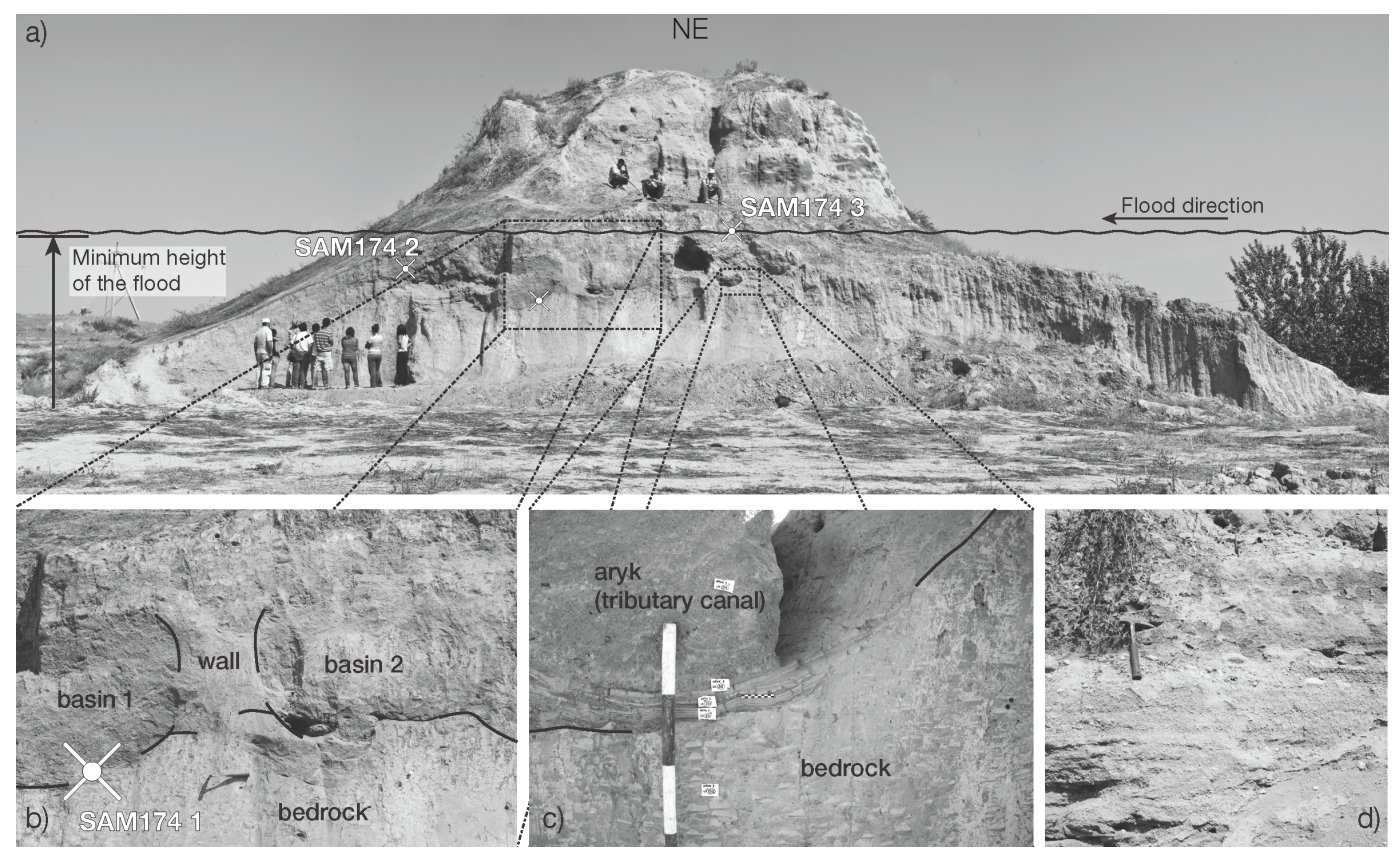

Figure 3 a) Excavations at SAM-174 as of 27 September 2009, picture taken looking NE. The crosses indicate the position of the ${ }^{14} \mathrm{C}$ samples; the flood direction was from right to left; b) close-up of 2 small hollows filled with coarse gray sand separated by a supporting wall (above the hammer); c) internal water canal; and d) local flood sediments.

Kafir Kala was a fortified complex with a central citadel surrounded by living quarters (called shahristan in Farsi) on the left bank of the Dargom, less than $1 \mathrm{~km}$ upstream from SAM-174 $\left(39.571944^{\circ} \mathrm{N}, 67.021389^{\circ} \mathrm{E}\right.$, Figure 4a). The archaeological investigation in the upper citadel provided the evidence of an important administrative center on the ancient local path of the Silk Road leading to Samarkand (Mantellini and Berdimuadov 2005). The development of the citadel was 
dated to the end of the Early Medieval period (7th century AD) and later reused as a residence during the Islamic period (8th-10th centuries AD).
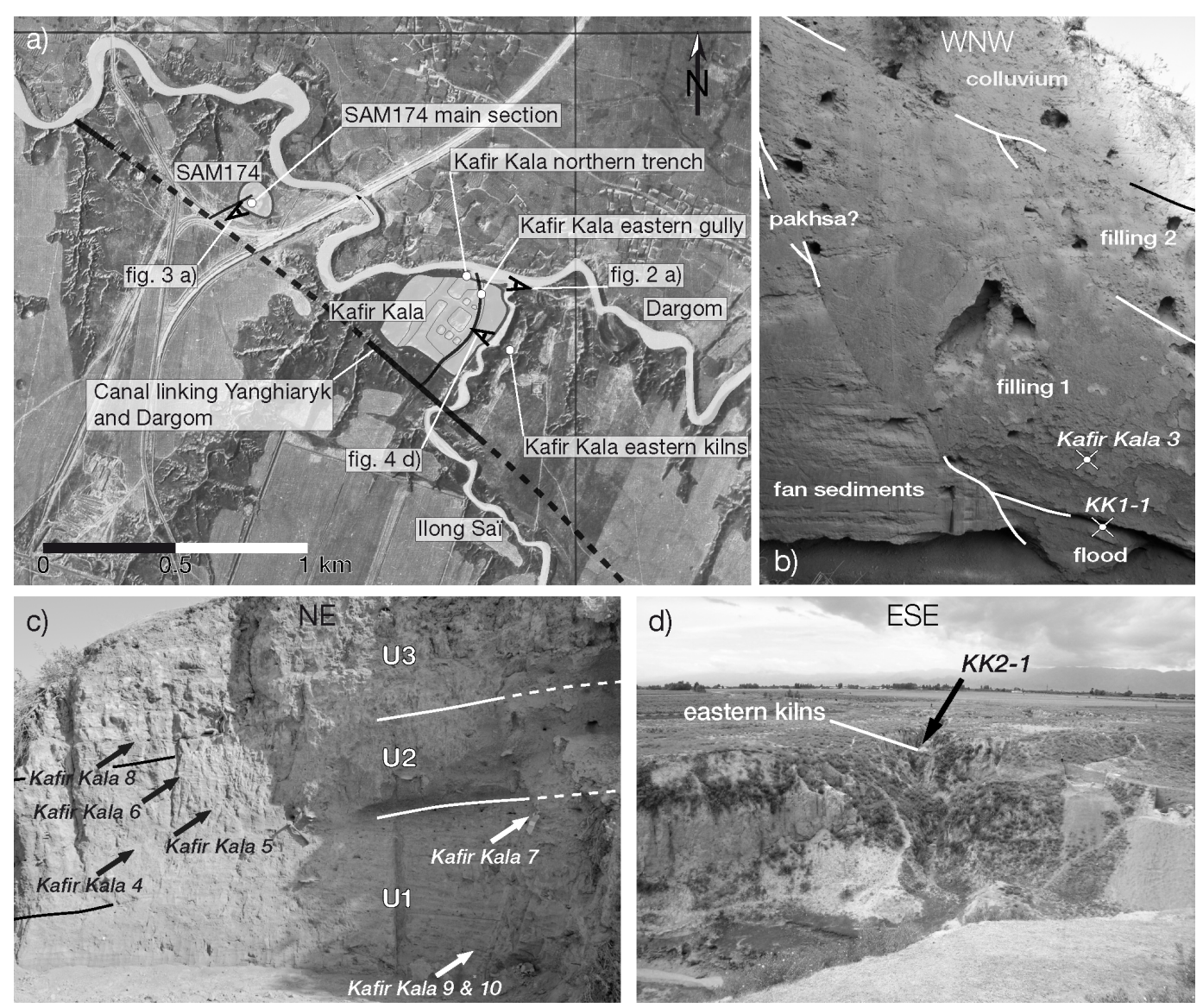

Figure 4 a) 1973 aerial picture of the sites Kafir Kala and SAM-174 with location of the sampling sites and of the presumed main ancient canals; b) profile in the northern trench looking west-northwest; c) section of the eastern small canal filled with at least $4 \mathrm{~m}$ of sediments; the picture is taken looking northeast; $\mathrm{d}$ ) location of the eastern kilns (pottery furnace).

A 30-m-long north-south trench dug in the old canal bank (reference TTN 2001 in Mantellini 2003) was opened between the northern shahristan and the modern Dargom (Figure 4b). The lowest unit is made of sediments of the local hillslope fans. A concave-upward artificial incision surface in this unit likely indicates the original bank of the Dargom. It is covered by a layer of coarse, poorly sorted, dark gray sand with cross-stratification, interpreted as a flood deposit, in the top of which we sampled a bone (KK1-1). The central section of the profile consists of 2 waste units composed of abundant bricks, bones, and pottery. A bone was picked in the lower unit (Kafir Kala 3). The top layer is made of colluvium. A thinner unit between the local sediments and the waste is interpreted as an artificial deposit of pakhsa placed there to protect the northern wall of the shahristan.

A small canal east of the northern shahristan was filled and subsequently re-incised by a small gully, conveniently providing a 4-m-deep view of the stratigraphic section (Figure 4c). After cleaning of this section, 3 main stratigraphic units were observed. The deepest unit, U1, is a stratified unit of 
red-ochre sands with many horizontal potsherds. U2 is a single unit of sand with some cross-laminations and pottery debris floating without organization within the sand. U3 is a stratified section of interfingered ochre-red and gray fine sand. Seven samples were picked along the section for ${ }^{14} \mathrm{C}$ dating. They are indicated by arrows in Figure 4c.

Outside the complex to the east, there is an early Medieval kiln workshop on the edge of the Ilon Sai Canal. This site lies next to an important waste-containing unit (lower in absolute stratigraphy). A bone (KK2-1) was sampled in this unit to assess the period of activity of the workshop.

Finally, Afrasiab $\left(39.671389^{\circ} \mathrm{N}, 66.988333^{\circ} \mathrm{E}\right)$ was an important political and economical center of western Central Asia until its destruction by the army of Genghis Khan in the first half of the 13th century AD. The site of Afrasiab was thereafter abandoned and the city was moved to the new site of Samarkand, a few kilometers to the south. Afrasiab lay close to the Zeravshan River, but it was built higher on its southern bank and had no direct access to its water. The city was supplied with water by canals coming from the southern flank of the valley (Grenet 2002). To test the hypothesis of an early connection between the Dargom and the water supply of Afrasiab, we sampled organic material for ${ }^{14} \mathrm{C}$ dating in sediments of the main canals and noted their mineralogy. The charcoal sample Afrasiab 1 was picked after removal of a few centimeters of in situ sediments below the first ceramic layer in a trench dug in 1996-97 through the Magistranlyy Kanal, i.e. the main of the 3 canals supplying the city from the south $\left(39.668211^{\circ} \mathrm{N}, 66.986556^{\circ} \mathrm{E}\right.$; Ivanitzkiy and Inevatkina 1999). The bone sample Afrasiab 4 was taken at the base of the Hellenic canal below the northern city wall $\left(39.675755^{\circ} \mathrm{N}, 66.988834^{\circ} \mathrm{E}\right)$.

\section{METHODS}

\section{Radiocarbon Dating}

As described above, 8 bones and 5 charcoals were sampled for ${ }^{14} \mathrm{C}$ dating from known archaeological horizons of 3 different archaeological sites around Samarkand. Most of these horizons were already relatively dated based on ceramic stratigraphy, but no absolute dating was available. The horizons were chosen for their proximity with the first traces of the Dargom Canal and the flood of SAM-174 in the stratigraphic record.

All ${ }^{14} \mathrm{C}$ samples but two (KK1-1 and KK2-1) were analyzed at the Laboratory of Ion Beam Physics at ETH Zurich; the others were analyzed at the Leibniz-Laboratory for Radiometric Dating and Isotope Research. The charcoal samples were prepared following the procedure described by Hajdas et al. (2004). The noncharcoal material was removed from the samples by scraping off and buoyancy separation in water. The charcoals were then treated with acid: first in $0.5 \mathrm{M} \mathrm{HCl}$ at $60{ }^{\circ} \mathrm{C}$ overnight; second in $0.1 \mathrm{M} \mathrm{NaOH}$ at $60{ }^{\circ} \mathrm{C}$ for a couple of hours; and finally again in $0.5 \mathrm{M} \mathrm{HCl}$ at $60{ }^{\circ} \mathrm{C}$ for $30 \mathrm{~min}$. After drying, between 2 and $2.3 \mathrm{mg}$ of charcoal were placed in small aluminum foil baskets for graphitization.

Carbon was extracted from the bone samples at ETH Zurich following the method described by Hajdas et al. (2009). The bone samples were first cleaned with ultrasound in demineralized water and their spongy parts were scrapped off with a scalpel. After drying, $2 \mathrm{~g}$ of bone were crushed to a fine powder. The samples were then demineralized in $05 . \mathrm{M} \mathrm{HCl}$ for $30 \mathrm{~min}$ at room temperature. The material was centrifuged and then dissolved in $0.2 \mathrm{M} \mathrm{HCl}$ at $80^{\circ} \mathrm{C}$ on a shaker for $48 \mathrm{hr}$. Collagen was then purified using an ultrafiltration method (Brown et al. 1988), and finally vacuum-dried prior to graphitization. Eventually, the processed bone and charcoal samples were burned in an elemental 
analyzer and graphite was produced from the $\mathrm{CO}_{2}$, with the automated graphitization equipment developed at ETH Zurich (Nemec et al. 2010; Wacker et al. 2010).

The samples KK1-1 and KK2-1 were prepared differently at the Leibniz Laboratory for Radiometric Dating and Isotope Research, according to the method of Longin (1971). The bones were mechanically cleaned, then treated with acetone, rinsed with demineralized water, and subsequently demineralized in $\mathrm{HCl}(\sim 1 \%)$. The samples were then treated with $\mathrm{NaOH}(1 \%)$ for $1 \mathrm{hr}$ at $20^{\circ} \mathrm{C}$ and again with $\mathrm{HCl}(1 \%)$ for $1 \mathrm{hr}$ at $20^{\circ} \mathrm{C}$. Collagen was dissolved overnight as gelatin, filtered on a $0.45-\mu \mathrm{m}$ pore silver filter, and freeze-dried. The combustion to $\mathrm{CO}_{2}$ was performed in a closed quartz tube together with $\mathrm{CuO}$ and silver wool at $900{ }^{\circ} \mathrm{C}$. The $\mathrm{CO}_{2}$ was reduced with $\mathrm{H}_{2}$ over $\sim 2 \mathrm{mg}$ of Fe powder as catalyst, and the resulting carbon/iron mixture was pressed into a pellet in the target holder.

After graphitization, the carbon isotopic ratios were measured using accelerator mass spectrometry (AMS) (Synal et al. 2007). The ${ }^{14} \mathrm{C}$ ages were calibrated using the OxCal v 3.8 program (Bronk Ramsey 1995, 2001) and the IntCal04 calibration curve (Reimer et al. 2004).

\section{XRD Analysis}

The mineral composition of the sands and fine sands present in the stratigraphic columns of the investigated archaeological sites was established with X-ray powder diffraction (XRD) analysis at the Institute of Petrology and Geochemistry at ETH Zurich. Sands were crushed to a fine powder and analyzed with a Lynxeye superspeed detector mounted on a Bruker AXS D8 advance diffractometer. We analyzed additional sand samples from the main sediment sources before they mixed downstream: the Zeravshan River sands; several sais at the foot of the Zeravshan ridge; and the Karatyube granodiorite intrusion. They served as comparative references to establish the source of the sands found in the stratigraphy of the archaeological sites.

\section{Numerical Modeling}

To test if damage at the tepa SAM-174 could be produced by an extreme rainfall event in local catchments in the absence of the canals, we employed a 2-dimensional numerical model of surface overland flow (Simpson and Castelltort 2006) to study a potential flood event. We only used the shallow-water dynamics part of the numerical model and did not consider erosion-sedimentation as we assumed an intense and short-lived event (a couple of hours maximum) without longer-term landscape evolution. The numerical code is based on Navier-Stokes equations for shallow water flow, and was solved here for steady-flow conditions using a finite volume method. The model has been tested and validated against several documented solutions.

We used the numerical model to calculate water flow velocities over a digital elevation model (DEM) of the study area extracted from the ASTER Global Digital Elevation Map (GDEM) project (www.gdem.aster.ersdac.or.jp). The area was selected to encompass the entire upstream drainage area and a large zone downstream of the tepa SAM-174 (indicated by a gray rectangle in Figure 1) to prevent boundary effects. The DEM-with a resolution of about $30 \times 30 \mathrm{~m}$ at the latitude of Uzbekistan-was resampled at 4 resolutions of $1000 \times 1000 \mathrm{~m}, 500 \times 500 \mathrm{~m}, 250 \times 250 \mathrm{~m}$, and $100 \times 100 \mathrm{~m}$ in order to test the influence of local roughness.

Lower resolution models produce an overall higher water depth because smoothing erases the small drainage channels that would otherwise drain a significant portion of the total water flow. To constrain the possible magnitude of the precipitation event that could have produced the flooding, we used the $100 \times 100 \mathrm{~m}$ model. It provides a good compromise between the undesirable effect of the very local modern topographic features from the 1960s Soviet land reform, expressed in the $30 \times$ 
$30 \mathrm{~m}$ DEM (Marconi et al. 2009), and the exaggerated water depth caused by excess smoothing of the surface (in $250 \times 250 \mathrm{~m}$ and larger DEMs).

\section{RESULTS}

\section{Results of ${ }^{14} \mathrm{C}$ Dating}

We sampled and dated 6 charcoals and 11 bones from the archaeological sites SAM-174, Kafir Kala, and Afrasiab (see Figure 1). Three of the samples had insufficient carbon and did not yield ages. The results of the remaining analyses are presented in Table 1.

Table 1 Results of ${ }^{14} \mathrm{C}$ dating on 5 charcoals and 8 bones sampled in the 3 archaeological sites considered in this study. ${ }^{14} \mathrm{C}$ ages are given with $1 \sigma$ error. The $\mathrm{C} / \mathrm{N}$ values are given only for bones prepared at ETH laboratory. The calibrated ages were produced with the data set IntCal04 (Reimer et al. 2004).

\begin{tabular}{|c|c|c|c|c|c|c|c|c|}
\hline $\begin{array}{l}\mathrm{Lab} \\
\mathrm{nr}\end{array}$ & Sample & Position & Material & $\begin{array}{l}{ }^{14} \mathrm{C} \text { age } \\
\mathrm{BP}\end{array}$ & $\begin{array}{l}\text { Calibrated age } \\
\text { (IntCal04) }\end{array}$ & $\begin{array}{l}\delta^{13} \mathrm{C} \\
(\%)\end{array}$ & $\begin{array}{l}\text { Fraction } \\
\mathrm{C} / \mathrm{N}\end{array}$ & $\begin{array}{l}\text { Amount } \\
\text { of C } \\
(\mathrm{mg})\end{array}$ \\
\hline $\begin{array}{l}\text { ETH- } \\
40177\end{array}$ & Afrasiab 1 & $\begin{array}{l}\text { Base of central } \\
\text { channel }\end{array}$ & Charcoal & $1865 \pm 30$ & $\begin{array}{l}\text { AD 70-230 } \\
(95.4 \%)\end{array}$ & -23.5 & - & 1.0 \\
\hline $\begin{array}{l}\text { ETH- } \\
40178\end{array}$ & Afrasiab 4 & $\begin{array}{l}\text { Main Hellenis- } \\
\text { tic channel }\end{array}$ & Bone & $2255 \pm 35$ & $\begin{array}{l}400-340 \mathrm{BC} \\
(33.5 \%) \\
330-200 \mathrm{BC} \\
(61.9 \%)\end{array}$ & -19.7 & 2.6 & 1.0 \\
\hline $\begin{array}{l}\text { ETH- } \\
40179\end{array}$ & SAM174 1 & $\begin{array}{l}\text { On flooded un- } \\
\text { derground floor }\end{array}$ & Charcoal & $1850 \pm 30$ & $\begin{array}{l}\mathrm{AD} 80-240 \\
(95.4 \%)\end{array}$ & -24.9 & - & 1.0 \\
\hline $\begin{array}{l}\text { ETH- } \\
40180\end{array}$ & SAM174 2 & $\begin{array}{l}\text { Sand unit be- } \\
\text { low colluvium }\end{array}$ & Charcoal & $-2470 \pm 30$ & Present & -31.8 & - & 0.6 \\
\hline $\begin{array}{l}\text { ETH- } \\
40181\end{array}$ & SAM174 3 & $\begin{array}{l}\text { Sand unit be- } \\
\text { low colluvium }\end{array}$ & Charcoal & $140 \pm 30$ & $\begin{array}{l}\text { AD } 1660-1780 \\
(42.9 \%) \\
\text { AD } 1720-1950 \\
(52.5 \%)\end{array}$ & -25.9 & - & 0.8 \\
\hline $\begin{array}{l}\text { KIA3 } \\
6774\end{array}$ & KK1-1 & $\begin{array}{l}\text { Top of flood } \\
\text { unit }\end{array}$ & Bone & $1699 \pm 29$ & $\begin{array}{l}\text { AD 256-304 } \\
(24.8 \%) \\
\text { AD 313-412 } \\
(70.6 \%)\end{array}$ & -13.34 & - & 3.9 \\
\hline $\begin{array}{l}\text { KIA3 } \\
6776\end{array}$ & KK2-1 & $\begin{array}{l}\text { Waste filling } \\
\text { below Ilon Sai } \\
\text { furnace }\end{array}$ & Bone & $675 \pm 25$ & $\begin{array}{l}\text { AD 1274-1314 } \\
(58.2 \%) \\
\text { AD 1356-1388 } \\
(37.2 \%)\end{array}$ & -16.94 & - & 4.1 \\
\hline $\begin{array}{l}\text { ETH- } \\
40184\end{array}$ & Kafir Kala 3 & $\begin{array}{l}\text { Waste filling } \\
\text { above cut bank }\end{array}$ & Bone & $655 \pm 30$ & $\begin{array}{l}\text { AD 1270-1330 } \\
(45.4 \%) \\
\text { AD 1340-1400 } \\
(50.0 \%)\end{array}$ & -14.6 & 2.53 & 1.0 \\
\hline $\begin{array}{l}\text { ETH- } \\
40186\end{array}$ & Kafir Kala 5 & $\begin{array}{l}\text { Trench in east- } \\
\text { ern gully }\end{array}$ & Bone & $1670 \pm 35$ & $\begin{array}{l}\mathrm{AD} 370-440 \\
(95.4 \%)^{*}\end{array}$ & -11.2 & 2.52 & 0.9 \\
\hline $\begin{array}{l}\text { ETH- } \\
40188\end{array}$ & Kafir Kala 7 & $\begin{array}{l}\text { Trench in east- } \\
\text { ern gully }\end{array}$ & Bone & $1615 \pm 30$ & $\begin{array}{l}\text { AD 375-435 } \\
(95.4 \%)^{*}\end{array}$ & -19.0 & 2.54 & 1.0 \\
\hline $\begin{array}{l}\text { ETH- } \\
40189\end{array}$ & Kafir Kala 8 & $\begin{array}{l}\text { Trench in east- } \\
\text { ern gully }\end{array}$ & Bone & $1640 \pm 30$ & $\begin{array}{l}\mathrm{AD} \mathrm{380-470} \\
(92.6 \%)^{*}\end{array}$ & -18.7 & 2.54 & 0.9 \\
\hline $\begin{array}{l}\text { ETH- } \\
40190\end{array}$ & Kafir Kala 9 & $\begin{array}{l}\text { Trench in east- } \\
\text { ern gully }\end{array}$ & Charcoal & $1645 \pm 35$ & $\begin{array}{l}\text { AD 340-425 } \\
(95.4 \%)^{*}\end{array}$ & -25.2 & - & 1.0 \\
\hline $\begin{array}{l}\text { ETH- } \\
40191\end{array}$ & Kafir Kala 10 & $\begin{array}{l}\text { Trench in east- } \\
\text { ern gully }\end{array}$ & Bone & $1650 \pm 35$ & $\begin{array}{l}\text { AD 355-425 } \\
(95.4 \%)^{*}\end{array}$ & -16.3 & 2.52 & 0.9 \\
\hline
\end{tabular}


1. SAM-174: 3 targets were sampled to constrain the ages of the destructive flood documented in the stratigraphy of the tepa. The first (SAM174 1), a charcoal, yielded an age of AD 80-240. The 2 other charcoals (SAM174 2 and SAM174 3) had much younger ages (AD 1660-1780/ $1720-1950$ and present day).

2. Kafir Kala: 2 bones were sampled in the trench north of the northern shahristan; KK1-1 yielded an age of AD 255-410 and Kafir Kala 3 gave an age of AD 1270-1400. A series of 7 successive samples was picked in the gully east of the fortress. This allowed us to use the Bayesian modeling of OxCal (Bronk Ramsey 1995, 2001) to calibrate the sequence of ${ }^{14} \mathrm{C}$ ages and minimize the corresponding calendar ranges. Out of the 7 samples, 5 yielded ages (Kafir Kala 4 and 6 did not contain enough carbon); the 5 ages are closely distributed between AD 355-425 (Kafir Kala 10) and 380-470 (Kafir Kala 8). They span the 3 units (U1, U2, U3) of the small eastern canal. Finally, the bone sampled next to the Medieval kilns (KK 1-2) yielded an age of AD 12741314, 1356-1388.

3. Afrasiab: 2 samples were taken from the canals feeding the city with water from the southern hillslopes. The first, Afrasiab 1, had an age of AD 70-230. The second, Afrasiab 4, yielded an age of 400-200 BC.

\section{Sediments Provenance and Surface Processes}

The mineralogical signatures of the 2 main sediment types deposited on the southern flank of the Zeravshan Valley differ only slightly. The 2 main sources - the Karatyube range (mostly granodiorite) and the Zeravshan range (mostly shale) - are the 2 end-members of the mixing series found in the local stratigraphy. In the field, the color contrast between the two is striking. The Zeravshan sediments are dark gray and borne by the Dargom and Yanghiaryk canals. They contain primarily quartz, muscovite, albite, diopside, and chamosite (Fe chlorite). The red sediments, mainly derived from the Karatyube, are the natural hillslope deposits and contain mostly quartz, Mg calcite, albite, muscovite, and chamosite. The discriminating criterion between the two is the lack of $\mathrm{Mg}$ calcite in the Zeravshan sands. Mg calcite is potentially the product of in situ leaching of plagioclase.

In SAM-174, 3 sand samples were collected. The color of the sands was correlated with the presence or absence of $\mathrm{Mg}$ calcite. The red fine sands at the base of the aryks contained Mg calcite, while the grayer coarser sands of the directly overlying unit lacked any traces of it. The last sample was taken in a flood unit next to the tepa and had the same signature as the upper unit in the aryk with additional calcite and gypsum, both probably derived from soil concretions observed in the field.

In Afrasiab, a sample of red sand from the main canal of the Achaemenid city yielded a composition of quartz, Mg calcite, anorthite, and muscovite.

\section{Flood Modeling Results}

To better understand the origin of flooding at the tepa SAM-174, we simulated an event with $4 \mathrm{hr}$ of precipitation at $60 \mathrm{~mm} / \mathrm{hr}$ and predicted the resulting height of overland flow around the site of the tepa (Figure 5). Such a rain event is comparable to the extreme, but rare, storm events occurring in the arid climate that prevailed at the time of the SAM-174 flood. Due to its position on a low-amplitude topographical shoulder, the tepa is in a zone of divergent flow. The water height predicted at points distributed along a 5-km line perpendicular to the flow direction (line on the Figure $5 \mathrm{~b}$ ) does not exceed $25 \mathrm{~cm}$ after $4 \mathrm{hr}$ of $60 \mathrm{~mm} / \mathrm{hr}$ precipitation. These simulations show that even a very large precipitation event seems unlikely to flood and destroy the tepa by overland flow from the surrounding hillslopes. To account for the observed destruction, a supplementary source for the flood is required. 

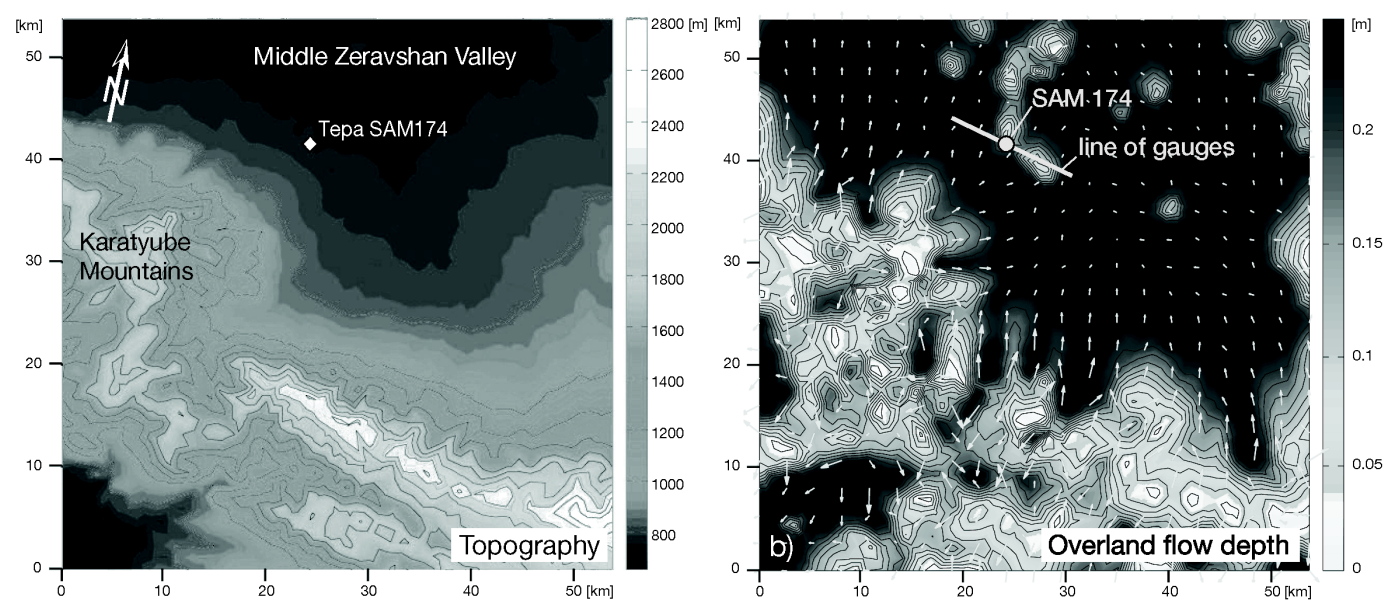

Figure 5 a) Topography of the area surrounding the archaeological sites; the tepa SAM 174 is marked by a diamond (see Figure 1 for the precise location); b) water height after $4 \mathrm{hr}$ of $60 \mathrm{~mm} / \mathrm{hr}$ precipitation; the light gray arrows indicate the direction of waterflow. Simulation completed with the $100 \times 100 \mathrm{~m}$ resolution DEM.

\section{DISCUSSION}

We have provided $13{ }^{14} \mathrm{C}$ ages to constrain the history of the Dargom and Yanghiaryk canals and we propose that the presence of dark gray sediments supports the existence of the canals by the late 2nd to early 3rd century AD. Furthermore, numerical modeling shows that heavy precipitation alone could not have produced the damages observed at the tepa SAM-174. Altogether, our results provide a rationale for the flooding of the tepa SAM-174 and anchor an important phase of the development of the Dargom and the Yanghiaryk canals around the 2nd century AD.

\section{The Flooding of SAM-174}

The sands filling the flooded small hollows are dark gray, and were hence deposited by water from one of the canals. SAM-174 was situated on the uphill bank of the Dargom. The water level of the Dargom in its early days lay, however, $7 \mathrm{~m}$ lower than the minimum height of the flood that swept SAM-174 (Marconi et al. 2009). Given the very broad profile of the Middle Zeravshan Valley $(>50 \mathrm{~km})$, such a high stand of the river with enough energy to damage a construction would require a water height of at least $40 \mathrm{~m}$ above the bed of the Zeravshan River. This hypothesis is to be rejected as no sign of such a large flood was found elsewhere in the Zeravshan Valley. Numerical simulation of water flow over the surrounding hillslopes completed in the present study show that even extreme precipitation events cannot account for the observed flooding by local overland flow at the site of tepa SAM 174, particularly since overland flow could not accumulate in this zone of divergent flow. A supplementary water input is thus required to explain the observed deposits and damage at the tepa. This implies the presence of a canal flowing above the tepa and carrying water derived from the Zeravshan River, such as the Yanghiaryk. We postulate that a failure of the Yanghiaryk levee could have released water that — channelized by the canal from which the tepa's watermill was operated - would have damaged the tepa. We also know from the stratigraphic facies of the local sediments that flooding was recurrent throughout the Holocene, a potential trigger for the failure of the levee. 


\section{Evidence for the Canals}

The study of SAM-174, Kafir Kala, and Afrasiab provided enough new data to establish spatial and temporal constraints for the irrigation system in the Middle Zeravshan Valley. The Yanghiaryk is traced back to at least AD 80-240 based on dating of material in the flood debris at SAM-174 and our demonstration that the flood itself attests to the existence of the canal.

In Kafir Kala, the existence of the Dargom is documented by gray sedimentary deposits in the northern trench and in the eastern gully (albeit indirectly). In the northern trench, the dark gray flood unit, which is the first layer over the artificial cut in the local fan sediments, was derived from the Zeravshan and borne by the Dargom, and dates from the late 2nd or early 3rd century AD (sample KK 1-1, Figure 4b). It is interpreted as the first deposit on what was either the Dargom Canal original bed or a local early adjustment of its bank. Although the bank is not directly dated, it is likely not much older than this first deposit. The eastern gully exposes the stratigraphy of a small canal that bordered the eastern wall of the citadel. This small canal was connected to the Dargom and the latter controlled its water height. The 5 successful ${ }^{14} \mathrm{C}$ ages obtained from this section document the history of a 2-stage fast filling between AD 340-425 and 380-470 (samples Kafir Kala 5, 7, 8, 9, and 10). The lowermost unit, U1, a series of layered local hillslope sediments, was the first deposition event in the canal. The top of $\mathrm{U} 1$ is cut by what was probably a man-made re-entrenchment of the canal. It is directly overlaid by a massive heterogeneous flood unit, U2, rich in debris and potsherds without particular orientation. U2 is presumably the result of the destabilization of the canal banks by the cleaning effort. Above U2, the regular deposition of the unit $\mathrm{U} 3$ points at a renewed fast filling of the canal until it reached the Dargom water level, at which point the canal was abandoned. However, the last deposits of U3 are made of interfingered ochre-red and dark gray fine sands, revealing an interplay between local sands and Dargom sands. In a later stage, following the natural entrenchment of the Dargom, the section has been incised by a gully. Hence, this section indirectly documents the evolution and water level of the Dargom between AD 340 and 425.

Finally, while there is clear evidence of the Dargom and the Yanghiaryk canals in the 2nd and 3rd centuries $\mathrm{AD}$, the contemporaneous section of the main feeding canal of Afrasiab (sample Afrasiab 1: AD 70-230) (Ivanitzkiy and Inevatkina 1999; Gentelle 2003) did not show any link with the canals. Its sand has a clear local hillslope signature: red with $\mathrm{Mg}$ calcite.

In Kafir Kala and SAM-174, the oldest traces of the Dargom and the Yanghiaryk date back to the 2nd and 3rd centuries AD, while Afrasiab's main canal appears to not have been connected to the main irrigation system.

\section{Climatic Considerations}

The modification of an irrigation system can be a response to a changing climate. To consider this, we would like to set the development of irrigation in the Samarkand Valley in a regional climatic framework. A compilation of climatic reconstructions for the region (Figure 6) helps to situate the flooding and the development of the Dargom relative to the climate evolution. The data compilation for western Central Asia is based on a wide array of proxies. The $\delta^{18} \mathrm{O}$ record of a speleothem of Soreq Cave in Israel (Schilman et al. 2002) is an indicator for the climate in the eastern Mediterranean Basin (for location, see Figure 1), the main source of moisture of the Aral catchment (Oberhänsli et al. 2007). It suggests a humid climate from 0 to $\mathrm{AD} 700$ and generally arid climate from $\mathrm{AD} 700$ to 1100. The global temperature evolution for the Northern Hemisphere is based on a large set of proxy records (Mann and Jones 2003; Jones and Mann 2004); the temperature is relatively steady in the 1st millennium AD and no particular trend is recorded. Temperature reconstruction in eastern China, based on phenological and historical data, shows a decrease of $\sim 1{ }^{\circ} \mathrm{C}$ in the first 

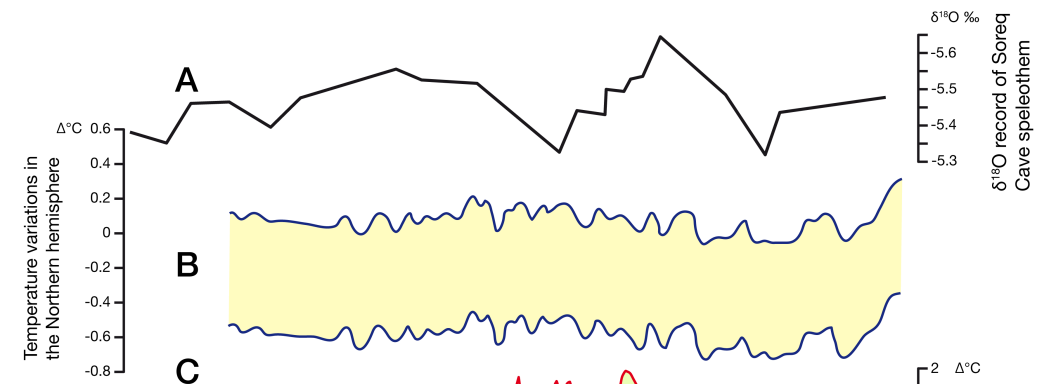

B
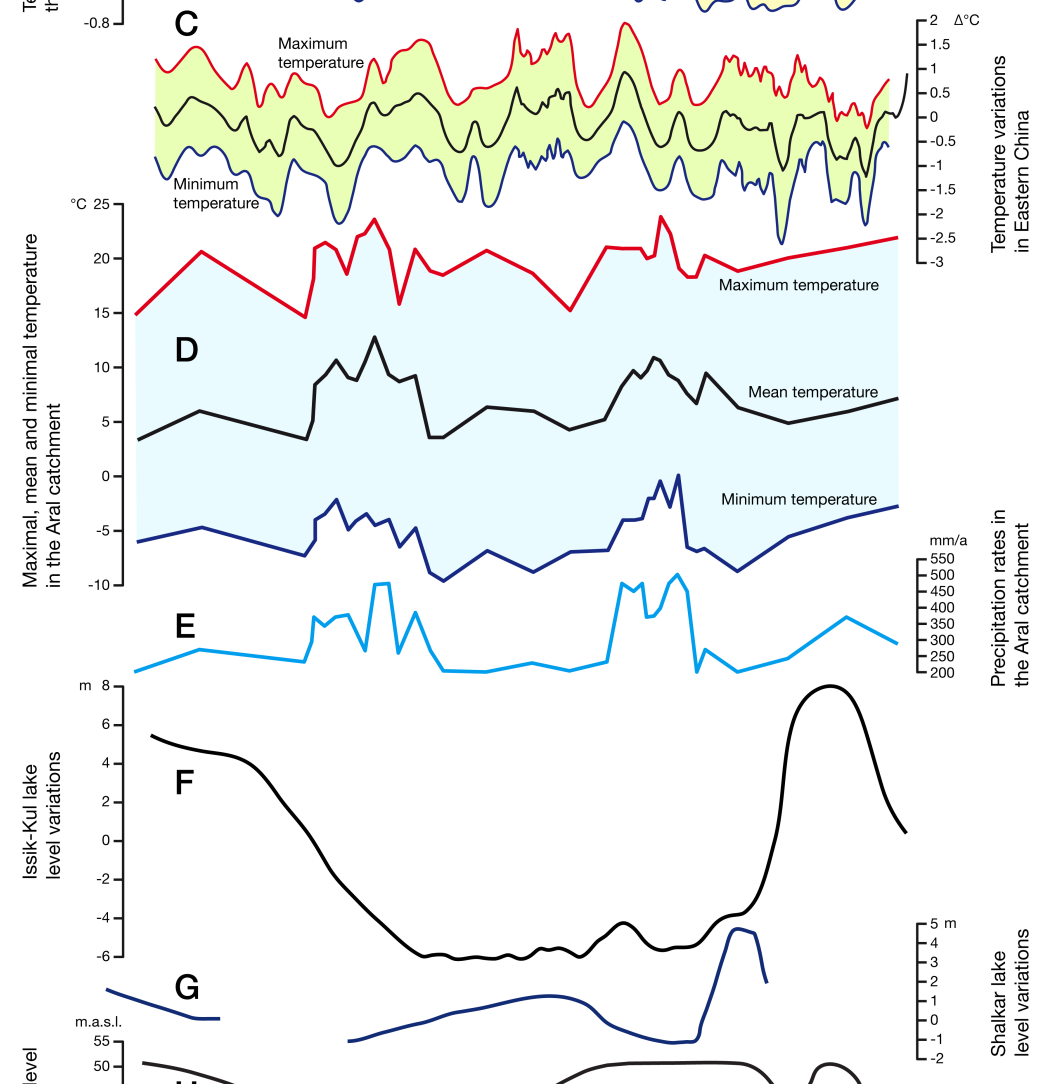

Archaeological periods

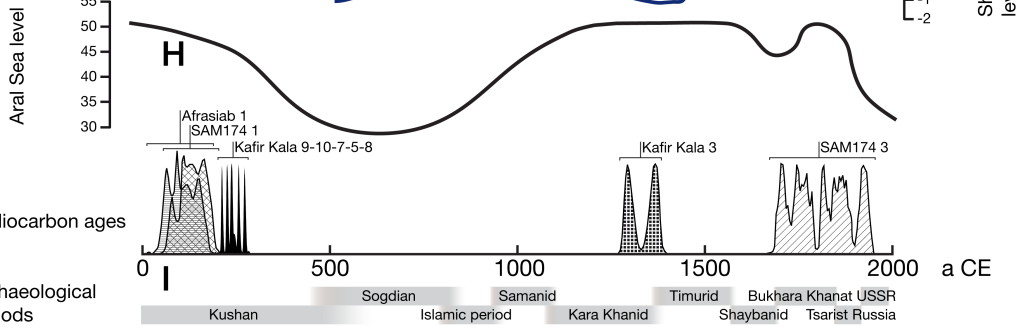

Figure 6 From top to bottom: A) $\delta^{18} \mathrm{O}$ speleothem record of Soreq Cave in Israel (Schilman et al. 2002); B) temperature reconstruction for the Northern Hemisphere based on a large set of proxy records (Mann and Jones 2003; Jones and Mann 2004); C) temperature reconstruction in eastern China based on phenological and historical data (Zheng et al. 2001); D) temperature reconstruction in the Aral catchment based on pollen records in the Aral Sea (Sorrel et al. 2007); E) precipitation reconstruction in the Aral catchment (Sorrel et al. 2007); F) reconstructed water level of Issik-Kul Lake in Kyrgyzstan (Shnitnikov 1980); G) reconstruction of the Shalkar Lake level in Kazakhstan (Shnitnikov 1975); H) reconstruction of the Aral Sea water level (Oberhänsli et al. 2007); and I) calibrated ${ }^{14} \mathrm{C}$ ages from this study and respective general archaeological periods in western Central Asia. 
6 centuries $\mathrm{AD}$ (Zheng et al. 2001). On a regional scale, the temperature reconstructions in the Aral catchment from pollen data (Sorrel et al. 2007) indicate 2 periods of increased variability (from about $\mathrm{AD} 400$ to 800 and from about $\mathrm{AD} 1200$ to 1500). However, we note that they are correlated with periods of higher data density. An overall rise of the temperature is nevertheless recorded between AD 400 and 700. The precipitation reconstruction from pollens in the Aral catchment is based on the same data as the temperature curves (Sorrel et al. 2007). Combined with the latter, they indicate an alternation of cold and arid periods with warmer and wetter periods. Further information is provided by reconstruction of water levels of 3 regional water bodies: Issik-Kul Lake in Kirghizstan; Shalkar Lake in Kazakhstan, north of the Caspian Sea; and the Aral Sea (for location, see Figure 1). The reconstructed water level of the Issik-Kul witnesses a sharp fall between AD 250 and 700 (Shnitnikov 1980). The Shalkar Lake level in Kazakhstan, although it is not a complete record, shows a decrease in the first centuries AD (Shnitnikov 1975). Finally, the water level of the Aral Sea documents a marked fall from 0 to AD 600. However, this reflects both climatic and anthropogenic forcing (Oberhänsli et al. 2007). The climatic reconstructions do not contain elements that could account for a sudden change of the climate potentially explaining the flooding of the tepa SAM-174. Although the climate of the region has remained overall steady, the fall of the lake levels indicates a likely increased aridity in the region.

\section{CONCLUSIONS}

To balance the scarcity of archaeological evidence in the Samarkand region for the development of irrigation in the early centuries $\mathrm{AD}$, we conducted and presented here a study combining sediment provenance, ${ }^{14} \mathrm{C}$ dating, flood modeling, and local stratigraphic analysis of deposits associated with the Samarkand Oasis canal system. Our work provides important results to constrain the development of the early irrigation system and the settlement dynamics of one of the most important central Asian oases. We establish several new spatial and temporal reference points for the history of the 2 main canals of the Middle Zeravshan Valley southern slopes:

1. The Yanghiaryk Canal very likely existed between AD 80 and 240 as documented by the flooding of SAM-174.

2. In the 2nd century AD, the Magistranlyy Kanal (main canal) in Afrasiab was not connected to the Dargom Canal.

3. In the late 2nd and early 3rd century AD, the Dargom Canal flowed in Kafir Kala and today's southern bank corresponds to its original bed.

The existence of the Dargom and the Yanghiaryk at the late 2nd to early 3rd centuries AD sets a minimal age for the large-scale irrigation of the southern flank of the Zeravshan Valley. It likely provided a background for the bloom of the Early Medieval and Islamic settlements (5th-9th centuries AD) (Stride et al. 2009; Codini 2010).

The extent of the early irrigation system to the west remains largely unknown and archaeological findings are rare at the moment. Further investigations are needed to complete our understanding of the role and the extent of the hydraulic work in the Samarkand Oasis. Application of the mixed approach successfully employed in this research could provide a methodology to address this question in the future.

\section{ACKNOWLEDGMENTS}

We thank the team of the Uzbek-Italian Archaeological Expedition at Samarkand, in particular, Giorgia Codini for the excavation of the section in the gully of Kafir Kala; Serena di Cugno, Elisa- 
betta Sedda, and Cristina Ambrosioni for the excavation of the site SAM-174; Rita Dimartino for the study of the pottery from the section of the gully in Kafir Kala and the site of SAM-174; Prof Giovanni Gabbianelli for his initial financial support. Lydia Zehnder and Eric Reusser for their support for XRD measurements. A final thanks go to Frantz Grenet, Claude Rapin, Mukhamadjan Isamiddinov, and Olga Inevatkina of the French-Uzbek Archaeological Expedition in Samarkand (MAFOuz) for providing data from Afrasiab.

\section{REFERENCES}

Andrianov BV. 1969. Drevnie orositel'nye sistemy priaral'ya. Moscow: Izdatel'stvo Nauka.

Andrianov BV. 1995. The history of economic development in the Aral region and its influence on the environment. GeoJournal 35:11-6.

Askarov KK. 1995. Selskaya okruga i ee rol v formirovanii rannesrednevekovogo Samarkanda (po materialam selskoy okrugi Samarkanda). Avtoref. Diss. Inst. Ist. Volume 12. Tashkent: Akademiya NAUK Uzb.

Bartold VV. 1977. Turkestan down to the Mongol Invasion. 4th edition. London: E J W Gibb Trust.

Berdimuradov AE, Tosi M, Mantellini S. 2010. UzbekItalian Archaeological Project: Samarkand and Its Territory; Season 2010, Preliminary Report. University of Bologna.

Bronk Ramsey C. 1995. Radiocarbon calibration and analysis of stratigraphy: the OxCal program. Radiocarbon 37(2):425-30.

Bronk Ramsey C. 2001. Development of the radiocarbon calibration program. Radiocarbon 43(2A):355-63.

Brown TA, Nelson DE, Vogel JS, Southon JR. 1988. Improved collagen extraction by modified Longin method. Radiocarbon 30(2):171-7.

Codini GB. 2010. Nomads and farmers in an urban context. An essay on the settlement of the Middle Zeravshan Valley at the edges of Samarkand region (Uzbekistan) [Nomadi e agricoltori nel contesto urbano. Un saggio sul popolamento della Media Valle dello Zeravshan ai margini della regione di Samarcanda (Uzbekistan)]. MA thesis (Tesi di Laurea Magistrale), University of Bologna, Department of Archaeology, Ravenna.

Fedchenko A. 1870. Topographical sketch of the Zarafshan Valley. Journal of the Royal Geographical Society of London 40:448-61.

Francfort H-P, Lecomte O. 2002. Irrigation et societe en Asie centrale des origines a l'epoque achemenide. $\mathrm{An}$ nales 57(3):625-63.

Gentelle P. 2003. Traces d'Eau: Un Géographe Chez les Archéologues. Paris: Editions Belin. p 172-32.

Grenet F. 2002. Samarkand I. History and Archeology. Encyclopaedia Iranica. Online edition.

Gulyamov YaG. 1975. Kushanskoe tsarstvo i drevnyaya irrigatsiya sredney azii. In: Trudy mejdunarodnoy konferentsii po istorii, arkheologii i kulture tsentralnoy azii v kushanskuyu epokhu (Dushanbe, 27 sentyabry 6 oktyabrya 1968). Tom I, Dushanbe, 1974, v. 120.
Hajdas I, Bonani G, Thut J, Leone G, Pfenninger R, Maden C. 2004. A report on sample preparation at the ETH/PSI AMS facility in Zurich. Nuclear Instruments and Methods in Physics Research B 223-224:267-71.

Hajdas I, Michczyński A, Bonani G, Wacker L, Furrer H. 2009. Dating bones near the limit of the radiocarbon dating method: study case mammoth from Niederweningen, ZH Switzerland. Radiocarbon 51(2):675-80.

Isamiddinov MK. 2002. Istoki gorodskoy kul tury samarkandskogo sogda. Tashkent: Izd-vo.

Ivanitzkiy ID, Inevatkina ON. 1999. Periodizatziya i etapi razvitiya vodosnabjeniya afrasiaba. Istoriya Materialnoy Kul 'tury Uzbekistana 30:96-103.

Jones PD, Mann ME. 2004. Climate over past millennia. Reviews of Geophysics 42: RG2002, doi:10.1029/ 2003RG000143.

Lebedeva TI. 1994. Selskaya okruga i ee rol v formirovanii rannesrednevekovogo Samarkanda (po materialam selskoy okrugi Samarkanda). Avtoref. Diss. Inst. Ist. Volume 12. Tashkent: Akademiya NAUK Uzb. p 22-3.

Lewis RA 1966. Early irrigation in West Turkestan. Annals of the Association of American Geographers 56: 467-91.

Longin R. 1971. New method of collagen extraction for radiocarbon dating. Nature 230(5291):241-2.

Mann ME, Jones PD. 2003. Global surface temperatures over the past two millennia. Geophysical Research Letters 30:1820, doi:10.1029/2003GL017814.

Mantellini S. 2003. The Dargom Canal and the Early Settlement of the Middle Zeravshan Valley. In: Pagani S, editor. Italo-Uzbek Scientific Cooperation in Archaeology and Islamic Studies: An Overview (Rome, 30 January 2001). Rome: Instituto Italiano per l'Africa e l'Oriente. p 41-8.

Mantellini S, Berdimuadov A. 2005. Archaeological explorations in the Sogdian Fortress of Kafir Kala. Ancient Civilizations from Scythia to Siberia 11(1-2): 107-32.

Mantellini S, Rondelli B, Stride S. 2011. Analytical approach for representing the water landscape evolution in Samarkand oasis (Uzbekistan). In: Jerem E, Redö F, Szeverényi V, editors. On the Road to Reconstructing the Past. Proceedings of the 36th Annual International Conference on Computer Applications and Quantitative Methods in Archaeology (CAA). Budapest, Hungary, 2-6 April 2008. p 388-96. 
Marconi V, Mantellini S, Picotti V, Gabbianelli G. 2009. The origin of the Dargom canal in the oasis of Samarkand (Uzbekistan). A new scenario from geoarcheological data. In: EGU General Assembly 2009. 19-24 April 2009, Vienna, Austria. p 6195.

Mukhamedjanov AR. 1975. K istorii irrigatsii v kushanskuyu epokhu. In: Trudy mejdunarodnoy konferentsii po istorii, arkheologii i kulture tsentralnoy azii v kushanskuyu epokhu (Dushanbe, 27 sentyabry - 6 oktyabrya 1968). Tom II, Dushanbe. v 278.

Mukhamedjanov AR. 1996. Economy and social system in Central Asia in the Kushan Age. In: Harmatta J, editor. History of Civilization of Central Asia. Volume 2. The Development of Sedentary and Nomadic Civilizations: 700 B.C. to A.D. 250. Paris: UNESCO Publishing. p 265-90.

Nemec M, Wacker L, Gaeggeler H. 2010. Optimization of the graphitization process at AGE-1. Radiocarbon 52(3):1380-93.

Oberhänsli H, Boroffka N, Sorrel P. 2007. Climate variability during the past 2,000 years and past economic and irrigation activities in the Aral Sea basin. Irrigation and Drainage Systems 21(3-4):167-83.

Reimer PJ, Baillie MGL, Bard E, Bayliss A, Beck JW, Bertrand CJH, Blackwell PG, Buck CE, Burr GS, Cutler KB, Damon PE, Edwards RL, Fairbanks RG, Friedrich M, Guilderson TP, Hogg AG, Hughen KA, Kromer B, McCormac G, Manning S, Bronk Ramsey C, Reimer RW, Remmele S, Southon JR, Stuiver M, Talamo S, Taylor FW, van der Plicht J, Weyhenmeyer CE. 2004. IntCal04 terrestrial radiocarbon age calibration, 0-26 cal kyr BP. Radiocarbon 46(3):102958.

Schilman B, Ayalon A, Bar-Matthews M. 2002. Sea-land paleoclimate correlation in the Eastern Mediterranean region during the late Holocene. Israel Journal of Earth Sciences 51:181-90.

Shirinov T, Tosi M. 2003. Land behind Samarkand. In: Pagani S, editor. Italo-Uzbek Scientific Cooperation in Archaeology and Islamic Studies: An Overview
(Rome, 30 January 2001). Rome: Instituto Italiano per l'Africa e 1'Oriente. p 13-41.

Shishkina GV. 1987. Ancient Samarkand and its surroundings (Drevniy Samarkand i ego okruga). In: $U r$ ban Culture of Bactria-Tokharistan and Sogdia: Antiquity and Early Middle Ages [Gorodskaya kultura baktrii-tokharistana i sogda: antichnosty, rannee srednevekove]. Material of the Soviet-French Colloquium (Samarkand, 1986) [Materialy sovetskogo-frantsuzkogo kollokviuma (Samarkand, 1986)]. Tashkent. p 167-70.

Shnitnikov AV. 1975. On the History of the Lakes of Northern Kazakhstan (Iz Istorii Ozer Severnogo Kazakstana). Leningrad: Nauka.

Shnitnikov AV. 1980. Lakes of the Tien Shan and Their History (Ozera Tian'-Shanya i ikh istoriya). Leningrad: Nauka.

Simpson G, Castelltort S. 2006. Coupled model of surface water flow, sediment transport and morphological evolution. Computers \& Geosciences 32(10): 1600-14.

Sorrel P, Popescu S-M, Klotz S, Suc J-P, Oberhänsli H. 2007. Climate variability in the Aral Sea basin (Central Asia) during the late Holocene based on vegetation changes. Quaternary Research 67(3):357-70.

Stride S, Rondelli B, Mantellini S. 2009. Canals versus horses: political power in the oasis of Samarkand. World Archaeology 41(1):73-87.

Synal H-A, Stocker M, Suter M. 2007. MICADAS: a new compact radiocarbon AMS system. Nuclear Instruments and Methods in Physics Research B 259(1): $7-13$.

Wacker L, Nemec M, Bourquin J. 2010. A revolutionary graphitisation system: fully automated, compact and simple. Nuclear Instruments and Methods in Physics Research B 268(7-8):931-4.

Zheng J, Zhang P, Ge Q, Man Z. 2001. Centennial changes of drought/flood spatial pattern in eastern China for the last 2000 years. Progress in Natural Science 11(4):280-7. 